\title{
Editorial
}

\section{The state of internal controls: Insights from the SEC roundtable}

On 13th April, 2005, the Securities and Exchange Commission (SEC) held a roundtable on the controversial Section 404 provisions of the Sarbanes-Oxley Act. A major topic of discussion was the distancing of relations between auditors and management as a result of the fear on the part of management of disclosing in a draft financial statement evidence of a significant deficiency or a material weakness. As might be expected, the staff of the Public Company Accounting Oversight Board (PCAOB) issued a policy paper calling on management to continue to share information with external auditors. Furthermore, the PCAOB expressed its opinion that control testing should be conducted throughout the year and began to discuss a risk-based approach as to which internal controls should be focused upon. The staff policy paper specifies that auditors should:

- integrate their audits of internal control with their audits of the client's financial statements, so that evidence gathered and tests conducted in the context of either audit contribute to completion of both audits;

- exercise judgment to tailor their audit plans to the risks facing individual audit clients, instead of using standardised 'checklists' that may not reflect an allocation of audit work weighted toward high-risk areas (and weighted against unnecessary audit focus in low-risk areas);

- use a top-down approach that begins with company-level controls, to identify for further testing only those accounts and processes that are, in fact, relevant to internal control over financial reporting, and use the risk assessment required by the standard to eliminate from further consideration those accounts that have only a remote likelihood of containing a material misstatement;

- take advantage of the significant flexibility that the standard allows to use the work of others; and,

- engage in direct and timely communication with audit clients when those clients seek auditors' views on accounting or internal control issues before those clients make their own decisions on such issues, implement internal control processes under consideration, or finalise financial reports.

But in contrast to this official call for more controls were the complaints of the business community at the roundtable that internal controls do not seem to be efficient in achieving the results intended. In general terms, the participants stressed that Board members were spending inordinate amounts of time on review of internal controls, that internal controls in one form or another had arrived on the scene with the Foreign Corrupt Practices Act 1977 and thus Sarbanes-Oxley was only a continuation of the process. Significantly, participants did not discuss the distinction between internal controls generally and internal controls over financial reporting. And while the cost of implementing Section 404 are perhaps manageable for Fortune 100 companies, the cost as a percentage of market capitalisation could be as much as 50 times as high for companies with less than $\$ 200 \mathrm{~m}$ in market cap.

The emphasis on IT in the implementation of internal controls, accounting for 
about $\$ 10 \mathrm{bn}$ out of $\$ 25 \mathrm{bn}$ expended on Section 404 in the first year, prompted a pointed reminder from the SEC staff policy paper that Section 404 does not imply any particular IT perspective. This also begs the question as to what the rest was spent on. While 'tone at the top' was addressed, it is not altogether evident that the tone at the top gave rise to a material weakness in any situation. Nor for that matter was 'effectiveness of the audit committee' the grounds for a finding of material weakness.

The range of internal controls documented for Fortune 100 companies ranged from 5,000-6,000 to 50,000-80,000. Given these numbers, it is hard to see how these controls can be reviewed by management let alone by the audit committee. Two reports on corporate governance were presented at the roundtable and provide anecdotal evidence on the current state of the board and its role in internal control. The first anecdote records a chief executive officer's (CEO's) reaction to a putative finding of material weakness:

'The anecdote is this and it happened in a board. This is not a committee, happily, that I am chairing. But it's a situation that I know a lot about. There was a material weakness determined toward the end of the process by the auditor, and the auditor and the CFO and actually the CEO, as I'm told, got into this, and they really had a terrible time of disagreement. So much so that the lead partner in this case is going to be removed. Somebody else is going to be put in there.' (Remarks of Ms Franklin, Panel 1)

Another anecdote recounts the meeting of a prospective independent director with a $\mathrm{CEO}$ and a chief financial officer (CFO):

'Let me give you an anecdote from a board perspective on how you assess tone at the top. About two years ago, I was invited to join the board of a Fortune 500 company and went out and visited with the CEO and some of the senior management for the first time. I didn't know these folks. I sat with the CEO for an extended period of time. I asked him to tell me about his control attitude and his internal audit staff. He explained to me that they didn't need an internal audit staff. Imagine being an audit committee member of a company that doesn't have an internal audit staff? You do your own risk assessment there. He said we look to our senior managers and their financial leadership to ensure we have good controls, and if something goes wrong, we fire them. So, we don't need an internal audit. I filed that away. He then invited his chief financial officer in to visit with me. The meeting went long enough and we drank enough coffee that the CEO had to finally leave the room. I had the opportunity to visit with the CFO.

I asked him how do the board meetings go, what kind of communication goes on there. I said I assume you start out with a financial presentation. He says, no, only the CEO makes presentations to the board. I said even the presentation of monthly or quarterly operating results. $\mathrm{He}$ said, yes, I've been here 17 years; I've never made a presentation to the board. I filed that away. At the conclusion of the visit, I went back to the chairman of the nominating committee and declined to join that board, and that individual said gee, when I first joined the board, I had the same concerns you did, but after a while, I got used to it.' (Remarks of $\mathrm{Mr}$ Noski, Panel 4)

It appears that this is the real state of the art of corporate governance. In so far as findings of material weakness are concerned, the market has largely ignored them. Part of the problem, as participants at the roundtable stated, was that a material weakness could 
signal anything from a complex tax problem to a real problem with financial reporting.

A great deal of expectation centred around the PCAOB inspection of registered accounting firms, and the insight or even closure this would bring to the definition of 'material weakness'. In the meantime, absent a clear definition, a great deal of time and money has been spent speculating about what might be a material weakness, at least in so far as IT can contribute to the solution.

An unfortunate aspect of Section 404 is the extent to which it has stifled communication between companies and auditors. Garret Stauffer, a Senior Partner from the National Risk and Quality Practice of PricewaterhouseCoopers made these remarks:

'No, it's not good policy. Clearly in our mind, it's an unintended consequence. It's driven bad behavior. It's prevented good communications. It has the impact of going backwards when you think about quality of financial reporting. I will say that early on, let's say right after the standard was issued last Summer, I believe there was a very, very stifling effect at that point in time. It has gotten better, I believe, as we sit here today. That's due to speeches made both by the SEC and the PCAOB, the PCAOB's FAQ on this topic. We, as I think industry, have made an effort to make sure we keep our partners and our staff informed on the issue and where the lines should be looked at.

Management can advocate its responsibility for the selection of generally accepted accounting principles. Management can have the auditor come in and record the journal entries and close the books and write the financial statements. We all know that. That is a far cry from what I think we are talking about here, which is good communication that will improve the quality of financial reporting.'

What then is the purpose of internal control reporting under Section 404? Certainly, it is of considerable benefit to the Big Four audit firms that have seen double digit increases in billings and profits. The additional income may come in useful when they are sued for failing to detect the absence of certain internal controls including 'tone at the top' and the 'effectiveness of the audit committee'.

Were internal controls to dictate the application of financial standards (even specific revenue recognition policies alone) the consequence would be greatly reduced earnings. Of course, internal controls as currently administered are only one indicator of financial weakness (Moody's has downgraded only 20 per cent of companies reporting material weaknesses).

While internal controls probably have some association with the accuracy of financial statements, the strength of that relationship has yet to be demonstrated. But the presence of internal control requirements is likely to make investors more comfortable with the accuracy of financial statements. Keynes compared the stock market to a beauty contest in which the average man picks the winner, and to the average investor, internal controls are beautiful.

Mr John Friedland Editor 